\title{
"Art Experiments and Cultural Preservation during a Pandemic: A Case Study Lembah Gana Festival in 2020"
}

\author{
Fajrul Falah $^{1 *}$, Khothibul Umam ${ }^{2}$, Suharyo ${ }^{3}$, and Gregorius Tri Hendrawan M. ${ }^{4}$ \\ ${ }^{1}$ Indonesian literature, Faculty of Humanities, Diponegoro University, Indonesia \\ ${ }^{2}$ Indonesian literature, Faculty of Humanities, Diponegoro University, Indonesia \\ ${ }^{1}$ Indonesian literature, Faculty of Humanities, Diponegoro University, Indonesia \\ ${ }^{4}$ Indonesian literature, Faculty of Humanities, Diponegoro University, Indonesia
}

\begin{abstract}
This study aims to reveal artistic expressions and forms of cultural preservation at the Lembah Gana Festival in Semarang Regency. This research is interesting to do because no research has been found on the Lembah Gana Festival. The urgency of this research lies in the introduction of cultural heritage, especially ancient Java. The problem is that most people forget about historical remains, both physically (tangible) and non-physically (intagible). The object and location of this research is the Lembah Gana Festival in Semarang Regency. This research is in the realm of ethnographic research. The research method used is document extraction, observation, and in-depth interviews to related parties. The research data were analyzed descriptively qualitatively. The novelty of the findings lies in the ability of the Lembah Gana Festival to bring back ancient Javanese culture. In addition, the research results show that the Lembah Gana Festival is increasingly existing and efforts to preserve culture have received enthusiasm from the people of Semarang Regency during the pandemic. The Festival Model which is conducted online, makes it easier for the audience to access.
\end{abstract}

\section{Introduction}

The development of the era of globalization and technological advances change people's behavior patterns and lifestyles [1]. Globalization has even triggered cultural products to contest creatively and openly [2 and 3]. Cultural products in Indonesia are indicated to be threatened by their existence if they cannot adapt to the times and accommodate changes in people's behavior. Especially when the Covid-19 pandemic is currently happening. Pandemics impact and exacerbate the situation by limiting human mobility/activities, thereby significantly changing human behavior patterns. How is the adaptation of cultural activities amid a pandemic? How is one of the efforts made to maintain or preserve culture in Indonesia? Culture becomes an identity and strengthens the unity of the nation.

Culture in this context is defined into three meanings. First, culture is identified in the choice of individual actions or decisions. An example of this definition is the habit of arriving late or on time (discipline). Second, culture refers to activities related to aesthetics/beauty. So culture is identified with art. Third, influential culture, ideas, beliefs, people's perspectives adapt to the environment [4]. In this study, the three meanings of culture are included but are more dominant in the second (art) and third (ideational/worldview) meanings. One form of

\footnotetext{
${ }^{*}$ Corresponding author: fajrul.falah@live.undip.ac.id
} 
genuine effort to preserve culture and attract attention is through the Lembah Gana Festival. The Lembah Gana Festival was initiated by the Karangjati Nyawiji Cultural Community, Bergas, Semarang Regency.

The Lembah Gana Festival, which contains arts and cultural activities, is indicated to preserve local cultural values and strengthen the identity of the local community. Especially if you look at the current era of globalization and the pandemic, the inheritor of the tradition of maintaining social collectivity is experiencing significant obstacles [5]. So the role of the Lembah Gana Festival is considered necessary. Are activities in pandemic conditions practical? What was the model or pattern of the Lembah Gana Festival during the pandemic? How are the efforts and challenges to deal with the globalization and pandemic situation? from here, it is necessary to create, innovate, and adapt culture amid a pandemic, introduce the cultural heritage of the past and introduce it to the current generation. Culture in the context of this research is specifically Old Javanese culture.

Based on internet searches and articles in online journals, research on the Lembah Gana has not been found. However, there are studies related to cultural preservation and preservation as follows. How to deal with the Covid-19 pandemic through local wisdom [6], cultural preservation efforts, and local wisdom values [7]. Traditional games and cultural preservation in Bali in the Industrial era 4.0 [8], preserving culture and arts [9]. Cultural preservation in the era of globalization [10], local wisdom amid the covid-19 pandemic [11]. Traditional art performances in Central Java as a form of Javanese language defense [12]. Local culture is the development and maintenance of the Javanese language [13]. Based on these studies, it can be conveyed that cultural activities can preserve culture in the local community. In addition, cultural preservation can strengthen national identity and unity. This research focuses explicitly on the Lembah Gana Festival amid a pandemic. If so, then the question is how to experiment with art (culture) to maintain and preserve culture during the Covid-19 pandemic?

\section{Method}

This research aims to uncover art experiments and defend culture amid a pandemic through the Lembah Gana Festival. To support this goal, work steps and data validation were carried out. The object and location of this research are the Lembah Gana in Karangjati, Semarang Regency. The type of research used is descriptive qualitative; the research object is understood holistically and deeply, not testing hypotheses through statistical formulas. The research data were obtained through literature study, observation, and in-depth interviews. Study literature/documents to obtain written information through reliable sources related to the activities or programs of the Lembah Gana Festival. Observations were made either directly or indirectly (online / youtube). To get an accurate description of the Lembah Gana festival program or activity. Interviews with related parties (stakeholders, performers, communities, audiences) were conducted to obtain a comprehensive picture, conditions, responses, and expectations regarding the Lembah Gana Festival. Research data obtained through literature studies, observations, and interviews were analyzed by comparing, categorizing, and interpreting according to their respective roles and functions. Interpretation is developed not based on the size of the researcher but the community studied.

\section{Result and Discussion}

The concept or idea of the Lembah Gana begins with an archaeological object in the form of a Ganesha statue. Arca Ganesha is located in Ngimbun Hamlet, Karangjati Village, Bergas District, Semarang Regency. The Karangjati Nyawiji Cultural Community then manages ganesha. In 2018 before the Covid-19 pandemic, the Karangjati Nyawiji Cultural Community took the initiative to have this place (the Ganesha statue) organized and open to the public. So the arrangement and repairs are carried out, such as cleaning the environment, repairing roads, building gazebos, and even toilets. These changes and arrangements are carried out in coordination with related parties Semarang Cultural Heritage Expert Team. The Ganesha statue or statue is made into a box and is proposed to be a cultural heritage object. The Lembah Gana was developed by the Karangjati Nyawiji Cultural Community not because it is commercial but because of its awareness of heritage (cultural heritage). 
Efforts to develop the Lembah Gana resulted in an idea, and a proposal was made. The proposal, which contained cultural programs, was later approved and named the Lembah Gana Festival. The name Lembah Gana came about not by chance but through related party discussions. Local people are more familiar with calling the Ganesha statue "Mbah Gono." So the name "Lembah Gana" was chosen as a marker of the local location. This name was later used as the name of the Archaeological Park and Cultural Education. The Lembah Gana Festival contains and focuses on ideas on making Old Javanese civilization an inspiration for work. Why the Old Javanese culture? Because the Ganesha statue is in Old Javanese civilization. Therefore, several arts and cultural activities were created that were oriented towards introducing and preserving Old Javanese culture.

\subsection{The Ganesha Statue Becomes the Center}

The Ganesha statue in the Lembah Gana is the center of inspiration for work (introducing culture). The Lembah Gana is unique and exciting because archaeological data is used as the basis for activities. This archaeological data can even be researched scientifically. This is different from some tourist villages, which do not have their respective archaeological objects. In terms of shape, this statue is different because it does not use a crownApart from statues as archaeological data; there are puppets. The challenge and hope in industry 4.0 and the current pandemic are how the archaeological data (statues) can be interpreted and remind people that there was civilization during the Old Javanese era. Efforts to improve and preserve this culture through festivals.

The Lembah Gana Festival is not the primary goal but a means of how the people interpret these historical relics for welfare in a broad sense (physical-spiritual). Among the philosophies of old Javanese historical relics is to treat nature well. Nature is the source of life. Therefore, usually in cultural heritage or sacred places, there is sacred springwater, and baths are interpreted to maintain cleanliness, even purification. If it is related to the present, for example, applying a clean lifestyle, not littering anywhere. This clean lifestyle is also very emphasized in today's pandemic conditions. The community applies a healthy lifestyle so that it is not susceptible to disease.

\subsection{Preserving Old Javanese Culture}

The Lembah Gana Festival contains activities to reintroduce Old Javanese culture. Experiments, activities, and forms of cultural preservation include traditional and contemporary dance performance arts, wayang performances, Javanese cultural literature, cultural gatherings, and writing workshops on palm leaves. Of course, activities related to Old Javanese culture are associated with current challenges and conditions. Literacy issues and programs are currently developing, so an activity, "Writing Workshop at Lontar," is created. The writing workshop was held to remind the millennial generation that palm leaves cannot be separated from the literacy and manuscripts of Old Javanese civilization. Before there were smartphones (smartphones), computers, and the internet, palm leaves were used as a documentation medium for knowledge and civilization in the archipelago, especially Old Java. Some of the current generation (young people) generally do not remember this cultural heritage of literacy.

The festival to preserve Old Javanese culture in this pandemic era has obstacles and challenges. Ideally, the festival should be held with direct participation and involve many people. However, due to the Covid-19 pandemic, there are rules for implementing health protocols; keep distance and reduce mobility. The festival is held online (virtual), not offline. Online festivals make people unable to get involved and feel the atmosphere directly. The festival organizing committee must also prepare the media (youtube) well.

On the other hand, the online festival (youtube/streaming) can be accessed and watched by many people and repeated. In terms of online reach and audience, this festival can increase and provide easy access. Even so, the festival is held both online due to the pandemic or not (offline), it is hoped that the younger generation will love the archipelago culture. People make (heritage) that culture as the pride and cultural wealth of the nation. 


\section{Conclusion}

The Lembah Gana Festival contains cultural activities based on the Old Javanese cultural civilization. Cultural experiments or festivals are held to protect and preserve the cultural heritage of the ancestors. People (especially the younger generation) are reminded of the civilization around the 7 th century through the festival. They can interpret it about the current condition. The Lembah Gana Festival is not the primary goal but a means of preserving past cultures based on archaeological data. The Lembah Gana Festival is adaptable and answers the challenges in this pandemic era. These artistic experiments, packed with new models, namely via virtual (streaming/youtube). These experiments and programs are easily accessible on the internet and can be viewed on social media (youtube and Instagram). The number of viewers and followers has the potential to continue to grow.

\section{References}

1. A. Maladi. Nsa. J. 12, 1 pp. 90-100. (2017).

2. A. Maladi. Theologia. J. 27 (1) pp. 212-236 (2016).

3. L. Margaretha, D.Sundawa. USA. J. 3 (2) pp. 64-72 (2016).

4. M.Thohir. Nsa. J. 14 (2) pp. 194-2015 (2019).

5. C. Pereira. Etnografica. J. 21 (1), 125-152 (2017).

6. S. Rumilah, et al. BSB. J. 2 (2), 119-129 (2020).

7. L. Herawati P, D. Riskiana A. JPBBS. 5 (1) 25-28 (2020).

8. M. Agus D, I. Ketut I.S. Senari (7), 329-335 (2020).

9. R. Fauzan, Nashar. Candrasgkl. 3 (1), 1-9 (2017).

10. H.M.I. Nahak. JSN. 5 (1), 65-76 (2019).

11. A. Satria N. JPS. 10 (1), 745-753 (2020).

12. H. Bakti M. Ltera. 15 (2), 269-280 (2016).

13. A. Tabrani, L. Sri A.P. Ltera. 16 (1), 96-104 (2017). 